\title{
Purification, Isolation, and Characterization of Esterase from Rhodococcus sp. LKE-021
}

\author{
Lekha Singh ${ }^{1,2} \mathbb{D}$, Gaurav Sharma ${ }^{1 *}(\mathbb{D})$, Asha Sharma ${ }^{3}(\mathbb{D})$ Gyanendra Awasthi² $^{(\mathbb{D}}$, \\ Lokendra Kumar ${ }^{2,4}(\mathbb{D})$, Mohammad Irfan Ali $^{1}$ (D) and Sarmad Moin ${ }^{1}$
}

${ }^{1}$ School of Applied Sciences, Suresh Gyan Vihar University, Jaipur, Rajasthan - 302 017, India. ${ }^{2}$ Department of Biochemistry, Dolphin PG Institute of Biomedical and Natural Science, Dehradun, Uttarakhand - 248007 , India. ${ }^{3}$ SW.P.N.K.S. Govt. P.G. College, Dausa - 303303, Rajasthan, India. ${ }^{4}$ Department of Microbiology, PM College of Education, Karsua, Aligarh, Uttar Pradesh - 202 001, India.

\begin{abstract}
A thermophilic esterase isolated from Rhodococcus $s p$. LKE-021. This enzyme was purified with purification fold 60 from the crude extracts of enzyme and recovery of enzyme obtained approximately 21\%. The specific activity of the LKE-021 esteraseis $795.1 \mathrm{U} / \mathrm{mg}$. SDS-PAGE analysis determined the molecular weight of LKE-21 esteraseis around $32,000 \mathrm{Da} / 32 \mathrm{KDa}$. The enzyme activity of LKE-021 esterase exhibited over a wide range of temperature i.e. $30^{\circ}$ to $80^{\circ} \mathrm{C}$ and the enzyme remained stable when incubated on $60^{\circ}$ for $2 \mathrm{~h}$. This indicates that the isolated LKE-021 esterase is thermostable. The isolated enzyme exhibits activity on various $\mathrm{pH}$ ranges from 2.0 to 12.0 and the highest activity observed on $11.0 \mathrm{pH}$.The LKE-021 esterase was active after proteinase $\mathrm{K}$ treatment and shows over $75 \%$ specific activity i.e. $50 \mathrm{U} / \mu \mathrm{g}$ Proteinase $\mathrm{K}$.
\end{abstract}

Keywords: Rhodococcus, isolation \& purification, characterization, Polyacrylamide Gel, Extremophiles

*Correspondence: gaurav.sharma@mygyanvihar.com; +91-9460032444

(Received: January 24, 2020; accepted: May 21, 2020)

Citation: Singh L, Sharma G, Sharma A, et al. Purification, Isolation, and Characterization of Esterase from Rhodococcus $s p$. LKE-021 .J Pure Appl Microbiol. 2020;14(2):1387-1395. doi: 10.22207/JPAM.14.2.36

(C) The Author(s) 2020. Open Access. This article is distributed under the terms of the Creative Commons Attribution 4.0 International License which permits unrestricted use, sharing, distribution, and reproduction in any medium, provided you give appropriate credit to the original author(s) and the source, provide a link to the Creative Commons license, and indicate if changes were made. 


\section{INTRODUCTION}

Extremophiles enzymes are the most promising for industrial applications. Thermophilic microorganisms producing a valuable thermostable enzyme stable in solvent and detergent, giving this enzyme considerable potential application in many industries ${ }^{1,2}$. According to Enzyme commission classification of enzyme lipases and esterases,are come in the hydrolases class and catalyze synthesis as well as hydrolysis of ester bonds. Ester compounds containing short-chain carboxylic acids and soluble in water hydrolyze by esterases (EC 3.1.1.1) whereas acyl-glycerides with long-chain catalyzes by lipases (EC 3.1.1.3) however the enzyme's 3D structures share the $\alpha / \beta$ hydrolase fold ${ }^{3,4}$.

Esterases are most abundant in the living organism and isolated from microorganisms, plants, as well asanimals ${ }^{5,6}$. The hydrolysis of fat and fatty acid esterssynthes is is catalyzed by Esterases 7,8 . Microbial esterases have enantioselectivity and regiospecificity as desired characteristics exhibiting considerable industrial potential ${ }^{9}$. The emergent importance of esterases in numerous aspects mainly in quantitation, targeted synthesis, production, and purification and therefore used in various fields and scientists produce enzymes from microorganisms, plants, and animals ${ }^{10}$. Esterases are exploited in the dairy industry, the beverage industry for the production of fruit juices, wine, alcohol,and beer. Esterases are employed in catalysts of trans-esterification to transform fats and oils of low-value into more valuable products. For instance, esterases isolated from Lactobacillus casei CL96 are exploited for milk fathydrolysis for flavor enhancement in cheese and its productsmanufacturing ${ }^{11,12}$.

Thermophilic microbes are important for the production of thermostable esterase. Esterase exhibits a tolerance against toxic compounds at a high level and resistance to denaturation leads to their extremophilic characteristics like salt tolerance, high temperature, and resistance to protease $^{13}$. Esterases have an extensive range of applications in combination with protease and amylase $^{14}$. The present research focuses on the esterase separation and characterization from Rhodococcus sp. LKE-021.

\section{MATERIALS AND METHODS \\ Separation of esterase}

Rhodococcus sp. LKE-021 was inoculated

in shake flasks method containing modified nutrient broth ( $\mathrm{pH} 7.0$ ) having $5.0 \mathrm{~g} / \mathrm{I} \mathrm{NaCl}$; $5.0 \mathrm{~g} / \mathrm{l}$ peptone; $3.0 \mathrm{~g} / \mathrm{l}$ yeast extract, and $10.0 \mathrm{~g} / \mathrm{l}$ glucose with constant shaking at $135 \mathrm{rpm}$ at $60^{\circ}$. After 24 hrs extracellular enzyme was recovered by centrifugation for $5 \mathrm{~min}$ at $10 \times 10^{3}$ relative centrifugal force in liquid fraction ${ }^{15}$.

Purification of Rhodococcus sp. LKE-021 esterase was done in four steps. The broth solution containing crude enzyme was cooled and slowly add the crystal of ammonium sulfate with constant stirring until $30 \%$ saturation achieve. At $4^{\circ} \mathrm{C}$ the solution was left overnight and centrifugation was done at $12 \times 10^{3}$ relative centrifugal force for $15 \mathrm{~min}$ and $4^{\circ}$ temperature maintained during centrifugation. To recover a one by the tenth volume of the crude sample, $20 \mathrm{Mm}$ Tris-Cl buffer dissolved in solution. Now the solution centrifuge $12 \times 10^{3}$ relative centrifugal force at $4^{\circ} \mathrm{C}$ for $15 \mathrm{~min}$ discarded the pallet. Estimation of the enzyme was done in the precipitated protein solution. Tris- $\mathrm{Cl}$ buffer $20 \mathrm{mM}, \mathrm{pH} 8.0$ used for dialyzed protein solution to remove the excess salt. The protein solution containing concentrated enzyme loaded onpre-equilibrated Diethylaminoethyl cellulosec column of size $2.2 \mathrm{~cm} \times 20 \mathrm{~cm}$ with $20 \mathrm{Mm}$ 2-Amino-2-(hydroxymethyl)propane-1,3-diol-HCl buffer (PH 8.0)(Himedia, India). The 2-Amino2-(hydroxymethyl)propane-1,3-diol-HCl buffer passed in the column until bound protein was eluted by Sodium chloride $(\mathrm{NaCl})$ gradient and $\Lambda 280$ $n m$ of effluent become zero. Each fraction of eluted volume i.e. $1 \mathrm{~mL}$ collected and fraction having high specific activity was lyophilized. Lyophilized sample dissolved in 2-Amino-2-(hydroxymethyl) propane-1,3-diol-HCl buffer of $20 \mathrm{mM}, \mathrm{PH} 8.0$ pre-equilibrated carboxymethylcellulose (Sigma) column of size $2.2 \mathrm{~cm} \times 25 \mathrm{~cm}$ used to running the sample. The columneluted with 2-Amino2-(hydroxymethyl)propane-1,3-diol-HCl buffer until zero absorbance at $\lambda 280 \mathrm{~nm}$ observed. Now bound protein eluted by $\mathrm{NaCl}$ of $0.05 \mathrm{M}$ in PH 8.0 of 2-Amino-2-(hydroxymethyl)propane-1,3-diol$\mathrm{HCl}$ buffer and the bioactive fraction collected. It passed to Sephadex-G100 column of size $2.25 \mathrm{~cm}$ 
$x 35 \mathrm{~cm}$ (Fluka Chemical) and the $1 \mathrm{~mL}$ fraction at $5 \mathrm{~mL} / \mathrm{h}$ of flow rate was collected and examined purification by SDS-PAGE. The pure enzyme fraction with bioactivity collected \& lyophilized for further characterization ${ }^{16}$.

Molecular mass determination and enzyme activity staining

SDS-PAGE performed according to Laemmli ${ }^{17}$ by using $7.5 \%$ polyacrylamide. For the molecular weight determination of the purified enzyme, 14-97 kDamarkers were used. $\beta$-mercaptoethanolomitted in the buffer. Silver staining used to visualized the protein bands and washed by 2-Amino-2-(hydroxymethyl)propane1,3-diol-HCl buffer of $7.5 \mathrm{pH}$ for $30 \mathrm{~min}$. Lastly, the gel was incubated in $2 \mathrm{mM}$ Fast Red TR (SigmaAldrich) in sodium sulfate buffer of $100 \mathrm{mM}, \mathrm{pH}$ 7.5. The activity of esterase estimated by the presence of a band of deep purple colored ${ }^{18}$.

$\mathrm{pH}$ and temperature effect on the activity of the enzyme

$\mathrm{pH}$ effect on activity of esterase examinedat $5.0-12.0 \mathrm{pH}$ ranges by several buffer solutions such as $50 \mathrm{mM}$, pH 5.0-6.0sodium acetate buffer, $50 \mathrm{mM}, \mathrm{pH}$ 6.0-8.0 potassium phosphate buffer, $50 \mathrm{mM}$; $\mathrm{pH}$ 7.0-9.02-Amino2-(hydroxymethyl) propane-1,3-diol-HCl buffer, $50 \mathrm{mM}, \mathrm{pH}$ 8.0-11.0 glycine- $\mathrm{NaOH}$ buffer, and $50 \mathrm{mM}, \mathrm{pH} 12.0 \mathrm{Na}_{2} \mathrm{HPO}_{4} \mathrm{NaOH}$ buffer at $70^{\circ} \mathrm{C}$. The activity of enzyme estimated by using P-nitrophenyl acetate (pNPA). Estimation of $\mathrm{pH}$ stability of lyophilized enzymes was done by incubation at $70^{\circ} \mathrm{C}$ for 2 hours and dissolved in buffers of various $\mathrm{pH}$. Reaction $\mathrm{pH}$ adjusted with similar buffer mentioned above and examined residual activity. The temperature effects estimated byusing pNPA at $20^{\circ} \mathrm{C}$ to $120^{\circ} \mathrm{C}$ at $\mathrm{pH} 11$. Thermostability estimated by incubation of enzyme at $60^{\circ} \mathrm{C}-90^{\circ} \mathrm{C}$ at $\mathrm{pH} 11$ for 2.5 hours ${ }^{16}$.

\section{Substrate specificity of the refined enzyme}

Substrate specificity estimated by measuring enzyme activity on substrate-like various fatty acid esters different pNP esters, triglycerides, and naphthyl esters ${ }^{16}$.

\section{p-Nitrophenyl esters}

Various pNP ester used with the standard assay method. The corresponding ester was substituted to pNP acetate ${ }^{19}$.

\section{$\alpha$-Naphthyl esters}

The enzyme $(250 \mu \mathrm{L}), \alpha$-Naphthyl acetate
$(50 \mu \mathrm{L})$ and glycine $\mathrm{NaOH}$ buffer $(200 \mu \mathrm{L})$ was mixed and incubated with Fast Red TR $(50 \mu \mathrm{L} 10 \mathrm{mM})$. degree of substrate hydrolysis was measured in terms of enzyme activity at $\Lambda 560$. Enzyme activity in one unit,defined as the quantity of enzyme used to discharge $1 \mu \mathrm{M}$ naphthol in one hour ${ }^{20}$.

\section{$\beta$-Naphthyl esters}

$\beta$-Naphthyl acetate $(50 \mu \mathrm{L})$, glycine $\mathrm{NaOH}$ buffer $(200 \mu \mathrm{L})$ and enzyme $(250 \mu \mathrm{L})$ mixed and incubated for 30 minutes and pour on to the ice to stop the reaction. The estimation of esterolytic activity observed at $\lambda 320 \mathrm{~nm}$. One unit enzyme activity determined as the amount of enzyme sufficiently liberating $1 \mu \mathrm{M} \beta$-naphthol in 1 hour $^{21}$.

\section{Fatty acid esters}

Titration method used for the determination of enzymatic hydrolysis of fatty acid. Fatty acid ester $(400 \mu \mathrm{L}$ of $10 \mathrm{mM})$, glycine $\mathrm{NaOH}$ buffer $(300 \mu \mathrm{L})$ and enzyme $(300 \mu \mathrm{L})$ was mixed and incubated for $30 \mathrm{mins}$ and reaction terminating by adding acetone, ethanol, and 10 $\mu \mathrm{L}$ of phenolphthalein (1\%). The mixture was titrated against $\mathrm{NaOH}(0.05 \mathrm{M})$ till thered color achieved. Lineweaver-Burk plotted for MichaelisMenten constant $\left(\mathrm{K}_{\mathrm{m}}\right)$ and rate of reaction $\left(\mathrm{V}_{\text {max }}\right)$ estimation ${ }^{22}$. A unit activity is defined as the quantity of enzyme consume to liberate fatty acid $(1 \mu \mathrm{M})$ in 1 hour.

Metal ions effect, denaturing chemicals, and inhibitors

Enzyme and Glycine $\mathrm{NaOH}$ buffer ( $50 \mathrm{mM})$ incubated at $70^{\circ}$ for 1 hour with various metal ions $\left(\mathrm{Ba}^{2+}, \mathrm{Cu}^{2+}, \mathrm{Ca}^{2+}, \mathrm{Fe}^{3+}, \mathrm{Co}^{2+}, \mathrm{K}^{+}, \mathrm{Hg}^{2+}, \mathrm{Mn}^{2}, \mathrm{Mg}^{2+}\right.$, and $\mathrm{Zn}^{2+}$ ), inhibiting agent (PMSF, lodoacetic acid and EDTA), oxidizers (hydrogen peroxide), reducing sugar ( $\beta$-mercaptoethanol) and $1 \%$ and $2 \%$ surface-active agent (SDS, Tween-80, TritonX-100, and Tween-20). pNP acetate utilized for the estimation of enzyme activity ${ }^{16}$.

\section{$\mathrm{NaCl}$ effect on the enzyme activity}

Enzyme activity due to the salinity effect estimated by using different $\mathrm{NaCl}$ concentrations (0 to $10 \mathrm{M}$ ). Enzyme incubatedat $70^{\circ} \mathrm{C}$ for $3 \mathrm{hrs}$ with glycine $(50 \mathrm{mM})$ and $\mathrm{NaOH}$ buffer with various concentrations of $\mathrm{NaCl}^{16}$.

\section{Organic solvents effect on the enzyme activity}

Purified enzyme stability estimated against various organic solvents. The enzyme, glycine $(50 \mathrm{mM})$, and $\mathrm{NaOH}$ buffer mixed with various organic solvent. The mixture incubated 
with moderate constant shaking at $70^{\circ} \mathrm{C}$ for 10 days. The related activity of the sample estimated at different days of intervals ${ }^{16}$.

Enzyme stability against protease

Stability against proteinase $\mathrm{K}$ (SigmaAldrich) assayed by refined enzyme incubated with various concentrations of proteinase at $70^{\circ} \mathrm{C}$ for 30 mins. The pNP substrate as acetate used to measure the activity of the enzyme ${ }^{16}$.

\section{RESULTS AND DISCUSSION}

\section{Separation of esterase}

The separation of the esterase from the isolate Rhodococcus sp. LKE-021 achieved 60 fold purification of the crude enzyme (Table 1). Purified LKE-021 esterase attained higher recovery (20.7\%) and specific activity (795.1 $\mathrm{U} \mathrm{mg}-1$ protein) in comparison with esterase recovery $14.4 \%$ isolated from Thermobifida fusca ${ }^{23}$.

Electrophoresis and zymography

Under the reduced conditions a band observed in SDS-PAGE signifying the esterase was homogeneous. The molecular mass of the LKE-021 Esterase discovered by SDS-PAGE is approximately $32,000 \mathrm{Da}$ (Fig. 1a). Zymogram of activity also shown one clear zone of esterolytic activity that confirmed the purification of LKE-021 Esterase at homogeneity level (Fig. 1b).

\section{pHeffect on the purified enzyme activity}

The highest activity of LKE-021 esterase shows on $\mathrm{pH} 11$. The LKE-021 esterase shows a broad range activity on pH 5-12 (Fig. 2). Fig. 3 illustrates the relative residual activity of LKE-021 esterase at various $\mathrm{pH}$ values after $30,60,90$ mins. This enzyme is stable in $5-11 \mathrm{pH}$ for a long as well as short duration. LKE-021esterase exhibited alkaliphilic nature. Alkaliphilic nature has been previously observed in enzymes extracted from extreme environmental condition ${ }^{16}$. Various $\mathrm{pH}$ and high temperatures require chemical methods recognized therefore enzymes muststabilize wide ranges of harsh conditions and there is anextensive interest in enzymes and their derivative isolated from extremophiles and without any pretreatment they are stable ${ }^{16,24}$.

Thermostability and optimum temperature of the purified enzyme

The LKE-021 esterase exhibits decent enzyme activity over a wide range of temperature

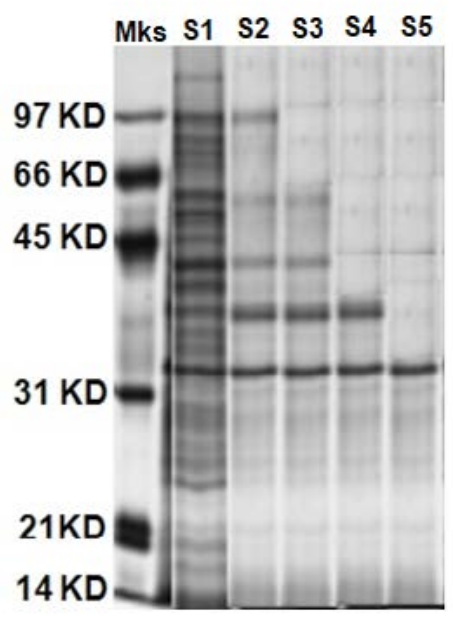

(a)

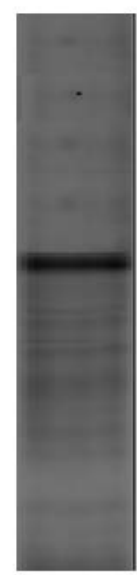

(b) (a) SDS-PAGE of the purified LKE-021 Esterase (b) Activity staining of LKE-021 purified Esterase Mks: Molecular weight marker

S1: Crude enzyme

S2: Precipitated crude enzyme

S3: Active fractions after steps of anionic exchange chromatography

S4: Active fractions after steps of cationic exchange chromatography

S5: Purified Esterase after steps of molecular sieving chromatography

Fig. 1. SDS-PAGE Gel of the purified LKE-021 Esterase

Table 1. Separation of Ike-021 esterase

\begin{tabular}{|c|c|c|c|c|c|}
\hline Purification step & $\begin{array}{c}\text { Total } \\
\text { Activity (U) }\end{array}$ & $\begin{array}{l}\text { Protein } \\
\text { (mg) }\end{array}$ & $\begin{array}{c}\text { Specific } \\
\text { Activity }(\mathrm{U} / \mathrm{mg})\end{array}$ & $\begin{array}{l}\text { Purification } \\
\text { fold }\end{array}$ & $\begin{array}{c}\text { Recovery } \\
\text { (\%) }\end{array}$ \\
\hline Crude extraction & 15720 & 1180 & 13.3 & 1.0 & 100 \\
\hline $0-30 \%\left(\mathrm{NH}_{4}\right)_{2} \mathrm{SO}_{4}$ fraction & 10890 & 94.7 & 114.9 & 8.64 & 69.2 \\
\hline DEAE ion-exchange & 6870 & 28.34 & 242.4 & 18.22 & 43.7 \\
\hline CM- ion-exchange & 4650 & 8.8 & 528.4 & 39.7 & 29.5 \\
\hline Sephadex gel-filtration & 3260 & 4.1 & 795.1 & 59.7 & 20.7 \\
\hline
\end{tabular}


$30-90^{\circ}$, the optimum activity being assayed at $70-80^{\circ}$ (Fig. 4).The profile of the thermal stability of LKE-021 esterase examined as residual activity (Fig. 5). The enzyme activated by maintaining at $30-70^{\circ}$ and nearly retained its optimum activity at $70^{\circ}$ for 2 hours of incubation. Though, the activity of the enzyme was lost at $90^{\circ}$ at $70^{\circ}$ for 2 hours of incubation. LKE-028 esterase exhibited a half-life $\left(t_{1 / 2}\right)$ of 60 mins at $90^{\circ}$ and at $80^{\circ} \mathrm{C}$ no significant reduction was detected. These results confer the work of Kumar et al., deliver a confirmation that LKE-021 esterase possesses exclusive properties for largescale production and application at extreme $\mathrm{pH}$ and temperature ${ }^{16}$.

\section{Metal ions effect on the enzyme activity}

All metal ions examined and observed that it inhibit the refinedLKE-021 to some level,

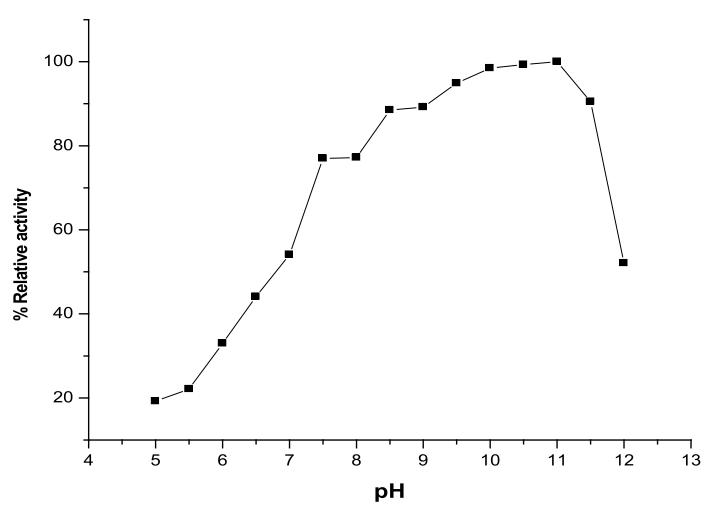

Fig. 2. $\mathrm{pH}$ effect on the LKE-021 activity

Table 2. Metal ions effect on the enzyme activity

\begin{tabular}{lcc}
\hline Metal ions & $\begin{array}{c}\text { Specific activity } \\
\text { (U/mg protein) }\end{array}$ & $\begin{array}{c}\text { \% Relative } \\
\text { activity }\end{array}$ \\
\hline Control & 795.1 & 100 \\
$\mathrm{CaCl}_{2}$ & 856.3 & 107.7 \\
$\mathrm{HgCl}_{2}$ & 73.94 & 9.3 \\
$\mathrm{FeCl}_{3}$ & 909.59 & 114.4 \\
$\mathrm{KCl}$ & 430.94 & 54.2 \\
$\mathrm{CuSO}^{4}$ & 509.65 & 64.1 \\
$\mathrm{CoCl}_{2}$ & 196.38 & 24.7 \\
$\mathrm{MgCl}_{2}$ & 821.33 & 103.3 \\
$\mathrm{FeSO}_{4}$ & 834.85 & 105.0 \\
$\mathrm{ZnSO}_{4}$ & 1141.76 & 143.6 \\
$\mathrm{BaCl}_{2}$ & 985.12 & 123.9
\end{tabular}

the LKE-021 esterase being inactivated to some extent by $\mathrm{HgCl}_{2}, \mathrm{CoCl}_{2}$ ions. Metal ions $\mathrm{Ba}^{+}, \mathrm{Zn}^{+}$, and $\mathrm{Fe}^{+}$improve the enzyme activity. The result of numerous metal ions on the activity of LKE-021 esterase is present in Table 2. It is familiar that metal ions are essential in maintaining protein integrity and stability by amino acid binding in specific sites of enzymes ${ }^{25}$. In the presence of $\mathrm{Zn}^{2+}$ and $\mathrm{Ba}^{2+} \mathrm{LKE}-021$ esterase activity was improved up to 143.6 and $123.9 \%$. These observations reflect similarities that describe Bachkatova and Severina ${ }^{26}$.

\section{Inhibitors affect enzyme activity}

The inhibitor's effect on enzyme activity shown in Table 3. The serine inhibitor (PMSF) completely inhibited the LKE-021 Esterase indicating that the Esterase comes in the hydrolase

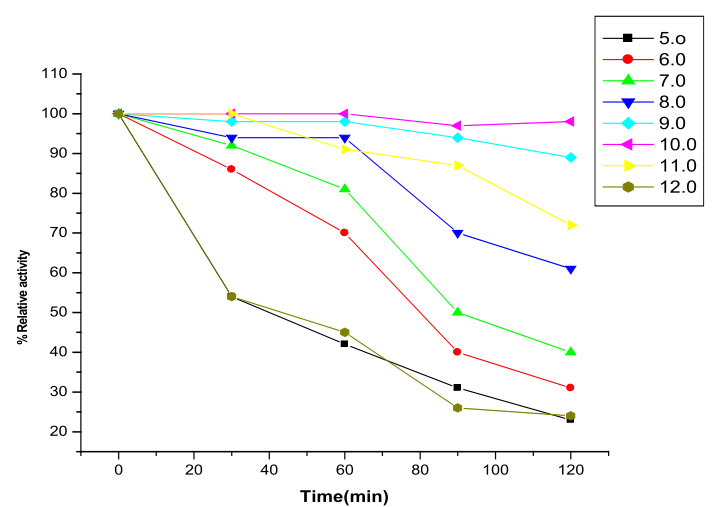

Fig. 3. pH effect on stability and activity of the refined LKE-021

Table 3. Effect of adifferent inhibitor of LKE-021

\begin{tabular}{lcc}
\hline Inhibitors & $\begin{array}{c}\text { Specific activity } \\
\text { (U/mg protein) }\end{array}$ & $\begin{array}{c}\text { \%Relative } \\
\text { activity }\end{array}$ \\
\hline EDTA & 704.29 & 88.58 \\
Idoacetic acid & 610.64 & 76.8 \\
SDS & 798.52 & 100.43 \\
$\beta$-mercaptoethanol & 527.31 & 66.32 \\
H202 & 625.58 & 78.68 \\
PMSF & 40.63 & 5.11 \\
Controle & 795.1 & $100 \%$ \\
Triton 1\% & 834.86 & 105 \\
Triton 2\% & 804.64 & 101.2 \\
Tween 20 1\% & 850.76 & 107.0 \\
Tween 20 2\% & 834.86 & 105.0 \\
Tween 80 1\% & 874.61 & 110.0 \\
Tween 80 2\% & 859.50 & 108.7
\end{tabular}


family of serine. Enhancement of the activity of Esterase observed in the company of surfactants like Tween 80 , Tween 20 , and triton (1\% to $2 \%$ ). In each case, the enzyme subjected to 1 hour of pre-incubation. LKE-021 Esterase is stable in both reducing and oxidizing conditions and the activity of esterase retained in the presence of $\beta$-mercaptoethanol and $\mathrm{H}_{2} \mathrm{O}_{2}$.

Salinity effect on the stability and enzyme activity

The purified LKE-021 Esterase shows great stability in $\mathrm{NaCl}$ about $100 \%$ activities when incubated with up to $10 \mathrm{M} \mathrm{NaCl}$. The enzyme activity observed about two times when mixed with $1 \mathrm{M} \mathrm{NaCl}$ and slightly decreases up to $3 \mathrm{M} \mathrm{NaCl}$ (Table 4). LKE-021 activity enhanced with $1 \mathrm{M} \mathrm{NaCl}$ and up to $10 \mathrm{M} \mathrm{NaCl}$ retained $100 \%$ activity and exhibited more halotolerant tha nearlier reported esterases $^{18,20}$.

\section{Substrate specific activity of LKE-021}

The activity of the LKE-021examined the effects of various substrates shown in Table5. The LKE-021 esterase was highly active on 4-Nitrophenyl butyrate and Ethyl laurate.

Table 4. Effect of salinity on LKE-021 esterase

\begin{tabular}{lcc}
\hline $\begin{array}{l}\text { Molarity } \\
\text { of NaCl }\end{array}$ & $\begin{array}{c}\text { Specific } \\
\text { activity(U/mg) }\end{array}$ & $\begin{array}{c}\text { Relative } \\
\text { activity (\%) }\end{array}$ \\
\hline Control & 795.1 & 100 \\
$1 \mathrm{M}$ & 1941.63 & 244.2 \\
$2 \mathrm{M}$ & 1798.51 & 226.2 \\
$3 \mathrm{M}$ & 1272.16 & 160.5 \\
$4 \mathrm{M}$ & 1209.34 & 152.1 \\
$5 \mathrm{M}$ & 865.86 & 108.9 \\
$10 \mathrm{M}$ & 823.7 & 103.6 \\
\hline
\end{tabular}

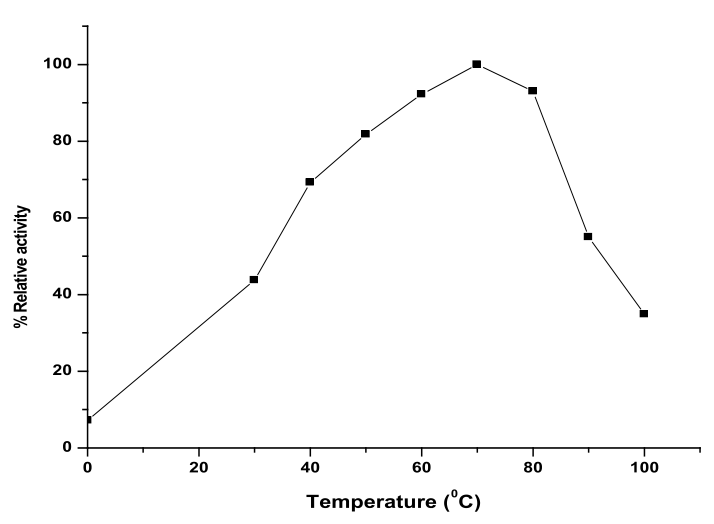

Fig. 4. Temperature effect on theactivity of LKE-021
On increasing the length of fatty acid and sidechain reduced activity of esterase. $\alpha$-naphthyl acetateis a superior substrate than $\beta$-naphthyl acetate. The esterase exhibits low activity against fatty acid striglycerides. Substrate specificity of purified LKE-021 esterase estimated by pNPs ubstrate and straight-chain fatty acidsethyl esters.

Table 5. Effect of different substrate on LKE-021 esterase

\begin{tabular}{|c|c|c|}
\hline Substrate & $\begin{array}{c}\text { Specific } \\
\text { activity }(U / \mathrm{mg})\end{array}$ & $\begin{array}{c}\text { Relative } \\
\text { activity (\%) }\end{array}$ \\
\hline 4-Nitrophenyl acetate & 795.1 & 100 \\
\hline 2-Napthyl acetate & 454.00 & 57.1 \\
\hline 4-Nitrophenyl palmitate & 181.28 & 22.8 \\
\hline Ethyl palmitate & 325.1 & 40.9 \\
\hline Ethyl linoleate & 223.34 & 28.09 \\
\hline \multicolumn{3}{|l|}{ 4-Nitrophenyl caprylate } \\
\hline 414.24 & 52.1 & \\
\hline Ethyl laurate & 681.40 & 85.7 \\
\hline 4-Nitrophenyl butyrate & 751.36 & 94.5 \\
\hline Ethyl oleate & 52.47 & 6.6 \\
\hline \multicolumn{3}{|l|}{ Ethyl caprylate } \\
\hline 192.4 & 24.2 & \\
\hline Ethyl lactate & 79.51 & 10.0 \\
\hline Ethyl decanoate & 249.66 & 31.4 \\
\hline Ethyl butyrate & 484.21 & 60.9 \\
\hline \multicolumn{3}{|l|}{ Ethyl isovalerate } \\
\hline 71.87 & 9.04 & \\
\hline Ethyl formate & 446.06 & 56.1 \\
\hline Ethyl octanoate & 95.41 & 12 \\
\hline Ethyl heranate & 0 & 0 \\
\hline Triactin & 196.38 & 24.7 \\
\hline Tributyrin & 116.87 & 14.7 \\
\hline Tripalmitin & 41.34 & 5.2 \\
\hline Trilaurin & 0 & 0 \\
\hline Isopropyl-myristata & 0 & 0 \\
\hline
\end{tabular}

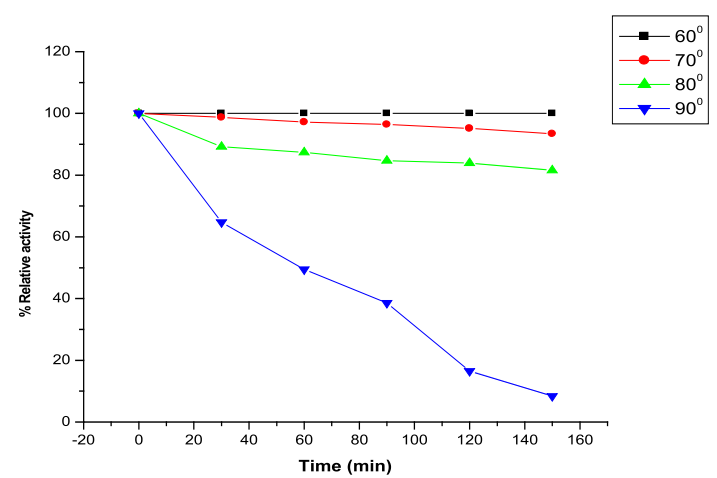

Fig. 5. Time effecton the activity and stability of LKE021 Esterase 
Esterase exhibits specificity of substrate on a set of substrates, Extreme activity of esterase was observed against pNP esters compared to ethyl esters.

Organic solvents Effect on the stability and activity of the LKE-021

The LKE-021 Esterase exhibits stability in Toluene, DMSO, Methanol, benzene, butanol, Isoamyl alcohol,and acetone. The enzyme was retaining decent activity even after 10 days in the Benzene, Isoamyl alcohol and DMSO as compared to the other solvent and it is highly stable in Benzene and DMSO and retaining good residual activity incubation with these organic solvents for 10 days at $37^{\circ} \mathrm{C}$ (Fig. 6). LKE-021 Esterase is stable as well as the activity enhanced in organic solvents. 1.1-1.7 fold specific activity of LKE-021 Esterase dramatically increased over 10 days in Benzene and DMSO as compared to the aqueous medium. Therefore these properties could be beneficial in numerous enzymatic processes in the industry. The esterases exploited in trans-esterification and biocatalytic esterification has $<1 \%$ water hence utilization of these esterases could be useful. The thermal stability of esterase could enhance by the use of these organic solvents ${ }^{27}$. LKE-021 esterase illustrated great stability in severalorganic solvents and maintained $100 \%$ relative activities subsequently 10 days in DMSO and toluene. The remarkable stability of LKE-21 esterase activity in organic solvents revealed by Karpushova ${ }^{18}$. Elend ${ }^{28}$ reported Metagenome derived esterase which exhibits the highest activity after incubation of 1 hour with 30\% and 15\% DMSO, while LKE028 esterase maintained $100 \%$ relative activity

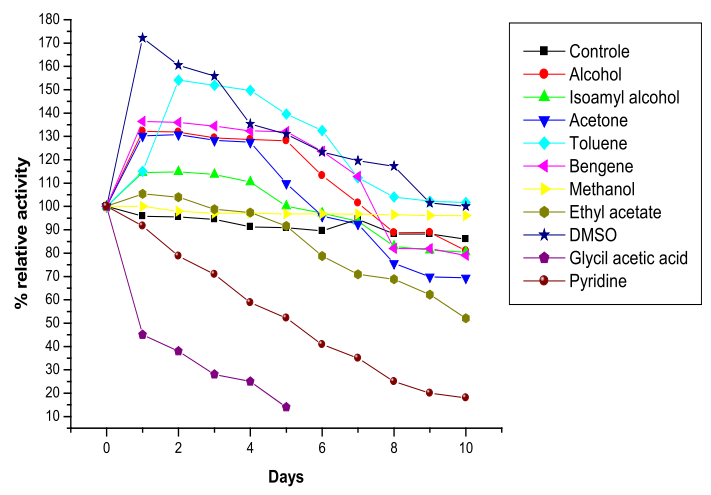

Fig. 6. Organic solvent'seffects on the stability of LKE021 esterase. subsequently 10 days of incubation and same observation revealed by Sana ${ }^{20}$ in BSE01 esterase isolated from Bacillus sp.

Compatibility of LKE-021 esterase with market available detergents and wash performance

The compatibility and stability of LKE-021

Esterase with most of the commercial laundry detergents like Wheel ${ }^{\circledR}$, Ariel $^{\circledR}$, Tide $^{\circledR}$, Surf excel $^{\circledR}$, Nirma ${ }^{\circledR}$, and Fena ${ }^{\circledR}$ as shown in the Fig. 7. It has shown good compatibility with Wheel and Surf excel detergents and more than $70 \%$ residual activity after 3 hrs. except the Nirma ${ }^{\circledR}$ and Fena ${ }^{\circledR}$ ${ }^{\circledR}$, detergent in all checked solid detergents. The stability and compatibility study of LKE-021 with most of the commercial laundry detergents at $37^{\circ} \mathrm{C}$ temperature was observed After $3 \mathrm{hr}$. in the following order: Wheel (128\%) > Surf excel (97\%) $>$ Ariel $(89 \%)>$ Tide $(89 \%) \%)>$ Nirma $(48 \%)>$ Fena (41\%).

Stability of LKE-021 esterase against protease

The LKE-021 esterase was observed active after proteinase $\mathrm{K}$ treatment and shows over $75 \%$ specific activity i.e. $50 \mathrm{U} / \mu \mathrm{g}$ Proteinase K (Table 6).

Table 6. Stability of esterase LKE-021 with proteinase $-\mathrm{K}$

\begin{tabular}{lcc}
\hline $\begin{array}{l}\text { Prot-k } \\
(\mathrm{U} / \mu \mathrm{g})\end{array}$ & $\begin{array}{c}\text { Specific } \\
\text { activity(U/mg) }\end{array}$ & $\begin{array}{c}\text { Relative } \\
\text { activity (\%) }\end{array}$ \\
\hline-- & 795.1 & 100 \\
5 & 786.35 & 98.9 \\
10 & 689.89 & 87.9 \\
20 & 652.78 & 82.1 \\
50 & 601.10 & 75.6 \\
100 & 194.00 & 24.4 \\
\hline
\end{tabular}

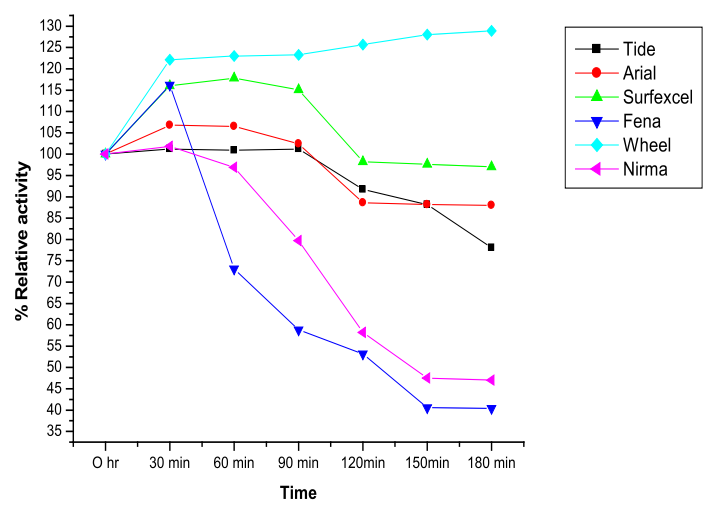

Fig. 7. Detergent compatibility test of LKE-021 Esterase on solid detergents 


\section{CONCLUSION}

LKE-021 esterasespecifies the extremophilic halophilic enzyme due to high salt tolerance. Thermostable, organic solvent, and salinity tolerant esterases might be exploited industrial applications such as effluent treatments, food industry for the production of interesterification substances, and non-natural hydrolysis of the substrate and alteration of molecules by nonaqueous biocatalysis. LKE-021 esterase shows potential uses in the non-aqueous biocatalyst due to stability and activity with protease, alkaline $\mathrm{pH}$,organic solvents, and high temperatures.

\section{ACKNOWLEDGMENTS}

The authors are sincerely thankful to $\mathrm{Mr}$. Sunil Sharma, Chancellor, and Dr. Sudhanshu, Chief Mentor of Suresh Gyan Vihar University, Jaipur, for providing a platform for this research.

\section{CONFLICT OF INTEREST}

The authors declare that there is no conflict of interest.

\section{AUTHORS' CONTRIBUTION}

LS - Extraction and Purification of LKE-021 esterase. GS - Electrophoresis and molecular mass determination of LKE-021 esterase. AS - Carried out LKE-021 esterase activity. GA - Effect of metal ions, inhibitors, and denaturing chemicals on LKE021 esterase activity. LK - Discussion writing. MIA - Formatting of paper as per Journal Guideline. SM - Grammatically checked and improved.

\section{FUNDING}

None.

\section{ETHICS STATEMENT}

This article does not contain any studies with human participants or animals performed by any of the authors.

\section{DATA AVAILABILITY}

All datasets generated or analyzed during this study are included in the manuscript and/or the Supplementary Files.

\section{REFERENCES}

1. Lasa I, Berenguer J. Thermophilic enzymes and their biotechnological potential. Microbiologia. 1993;9(2):77-89.

2. Haki GD, Rakshit SK. Developments in industrially important thermostable enzymes: a review. Bioresour Technol. 2003;89(1):17-34. https://doi.org/10.1016/ S0960-8524(03)00033-6

3. Nardin M, Dijkstra BW. $\alpha / \beta$ Hydrolase fold enzymes: the family keeps growing. COSB. 1999;9(6):732-737. https://doi.org/10.1016/S0959-440X(99)00037-8

4. Levisson M, van der Oost J, Kengen SW. Carboxylic ester hydrolases from hyperthermophiles. Extremophiles. 2009;13(4):567. https://doi.org/10.1007/s00792-0090260-4

5. Thomas TC, Szekacs A, Hammock BD, Wilson BW, McNamee MG. Affinity chromatography of neuropathy target esterase. Chem Biol. 1993;87(1-3):347-360. https://doi.org/10.1016/0009-2797(93)90063-5

6. Shahjahan RM, Karim A, Begum RA, Alam MS, Begum $A$. Tissue specific esterase isozyme banding pattern in Nile tilapia (Oreochromisniloticus). Univ j zoolRajshahiUniv, 2008; 27: 1-5. https://doi. org/10.3329/ujzru.v27i0.1943

7. Jaeger KE, Dijkstra BW, Reetz MT. Bacterial biocatalysts: molecular biology, three-dimensional structures, and biotechnological applications of lipases. Annu Rev Microbiol, 1999; 53(1): 315-351. https://doi. org/10.1146/annurev.micro.53.1.315

8. Lopes DB, Fraga LP, Fleuri LF,Macedo GA. Lipase and esterase: to what extent can this classification be applied accurately. J Food SciTechnol,2011;31(3):603-613. https://doi.org/10.1590/S0101-20612011000300009

9. Jaeger KE, Ransac S, Dijkstra BW, Colson C, van Heuvel M, Misset O. Bacterial lipases. FEMS Microbiol Rev, 1994; 15(1):29-63. https://doi. org/10.1111/j.1574-6976.1994.tb00121.x

10. Panda T,Gowrishankar BS. Production and applications of esterases. Appl Microbiol Biotechnol, 2005;67(2):160-169. https://doi.org/10.1007/s00253004-1840-y

11. Choi YJ, Lee B. Culture conditions for the production of esterase from Lactobacillus casei CL96. Bioproc Biosyst Eng,2012;4(1):59-63.

12. Torres S, Martinez MA, Pandey A, Castro GR. An organicsolvent-tolerant esterase from thermophilic Bacillus licheniformis S-86. BioresourTechnol, 2009;100:896902. https://doi.org/10.1016/j.biortech.2008.07.009

13. Rigoldi F, Donini S, Redaelli A, Parisini E, Gautieri A. Engineering of thermostable enzymes for industrial applications. APB, 2018;2(1):011501. https://doi. org/10.1063/1.4997367

14. Raveendran $S$, Parameswaran B, BeeviUmmalyma $S$, Abraham A, Kuruvilla Mathew A, Madhavan, A, et al. Applications of microbial enzymes in food industry. Food Technol Biotech, 2018;56(1):16-30. https://doi. org/10.17113/ftb.56.01.18.5491

15. Singh L, Sharma G, Awasthi G, Kumar L, Ali MI,Moin S. Screening, Isolation and Identification of Thermophilic Esterase Enzyme Isolated from Rhodococcus $s p$ : LKE021, J Pure Appl Microbiol, 2019;13(3):1855-1861. https://doi.org/10.22207/JPAM.13.3.63

16. Kumar L, Singh B, Adhikari DK, Mukherjee J, Ghosh D. A thermoalkaliphilic halotolerant esterase from 
Rhodococcussp. LKE-028 (MTCC 5562): enzyme purification and characterization. Process Biochem, 2012;47(6):983-991. https://doi.org/10.1016/j. procbio.2012.03.020

17. Laemmli UK. Cleavage of structural proteins during assembly of head of bacteriophageT4. Nature (London), 1970;227:680-685. https://doi. org/10.1038/227680a0

18. Karpushova A, Brummer F, Barth S, Lange S, Schmid RD. Cloning, recombinantexpression and biochemical characterisation of novel esterases from Bacillus sp.associated with the marine sponge Aplysina aerophoba. Appl Microbiol Biotechnol, 2005;67: 59-69. https://doi.org/10.1007/s00253-004-1780-6

19. Zhang J, Liu J, Zhou J, Ren Y, Dai X, Xiang H. Thermostable esterase from thermoanaerobacter tengcongensis: high-level expression, purification and characterization. Biotechnol Lett, 2003; 25: 14631467. https://doi.org/10.1023/A:1025076121700

20. Sana B, Ghosh D, Saha M, Mukherjee J. Purification and characterization of an extremely dimethylsulfoxide tolerant esterase from a salt-tolerant Bacillus species isolated from the marine environment of the Sundarbans. Process Biochem, 2007; 42:1571-1578. https://doi.org/10.1016/j.procbio.2007.05.026

21. Hou WC, Chen HJ, Chang CF, Lin YH. Purification and characterization of fattyacid esterase from Yam (Dioscorea batatas Decne) tuber. Bot Bull Acad Sinica, 1999;40:305-310.

22. Suzuki T, Nakayama T, Kurihara T, Nishino T, Esaki N. A cold-active esterase with a substrate preference for vinyl esters from a psychrotroph, Acinetobacter $s p$. strain no. 6: gene cloning, purification, and characterization. J Mol Catal B Enzyme, 2002;16: 255263. https://doi.org/10.1016/S1381-1177(01)00070-4

23. Yang $\mathrm{CH}$ and Liu WH. Purification and properties of an acetylxylan esterase from Thermobifida fusca. Enzyme MicrobTechnol, 2008;42(2):181-186. https:// doi.org/10.1016/j.enzmictec.2007.09.007

24. Morana A, Di Prizito N, Aurilia V, Rossi M, Cannio R. A carboxylesterase from the hyperthermophilic archaeon Sulfolobussol fataricus: cloning of the gene,characterization of the protein. Gene, 2002;283: 107-115. https://doi.org/10.1016/S03781119(01)00879-4

25. Colak A, Pipik D, Saglam N, Guner S, Canakci S, Belduz AO. Characterization of athermoalkalophilic esterase from a novel thermophilic bacterium, Anoxybacillus genensis G2. Bioresour Technol, 2005;96:625-631. https://doi.org/10.1016/j.biortech.2004.06.003

26. Bachkatova NA, Severina LO. Isolation and characterization of intracellularlipase from $S$. marcescens 345. Prikl Biokhim Mikrobiol, 1980;16:315326.

27. Heitmann P. In: Ruttoff H, editor. Industrial enzyme. Hamburg: Behr's Verlag., 1994, p. 913.

28. Elend C, Schmeisser C, Leggewie C, Babiak P, Carballeira $\mathrm{JD}$, Steele $\mathrm{HL}$, et al. Isolation and biochemical characterization of two novel metagenome derived esterases. Appl Environ Microbiol, 2006;72:3637-3645. https://doi.org/10.1128/AEM.72.5.3637-3645.2006 